\title{
Ngenger tradition and ideology transformation in inter-cultural communication
}

\author{
Anang Masduki \\ School of Journalism and Communication, Shanghai University, China. \\ Email: anang.shanghaiuniversity@gmail.com
}

Dani Fadillah

School of Communication and Journalism, Nanjing Normal University, China.

Email:31183006@stu.njnu.edu.cn

Fajar Dwi Putra

Asisstant Profesor at Universitas Ahmad Dahlan Yogyakarta, Indonesia.

Email: jokadesanta@yahoo.com

\begin{abstract}
In Tempurejo, Ngawi, between the 1960s and 1970s, many Ponorogo residents chose to ngenger. Ngenger is living and working sincerely, not paying to a household of someone whose position is much higher in dignity, degree, and education. Children who come to ngenger the background are poor and have the ideology of the Nahdlatul Ulama (NU) mass organization or abangan. After finishing ngenger, the majority turned into Muhammadiyah activists and developed Muhammadiyah in Ponorogo. From the above problems, this study intends to reveal, First, the process of planting Muhammadiyah ideology. Secondly, there is an ideological transformation. This research was conducted in Ngawi and Ponorogo with qualitative descriptive methods. In-depth interviews, observation, and documentation of extracted data. The study results are the regeneration process carried out first; they see Muhammadiyah as an open,
\end{abstract}


modern, professional organization. Second, families are open-minded and not doctrine. Third, the exemplary of educators and community leaders who have sincerity, the spirit of struggle, and the principle of the emphasis on the importance of Islamic da'wah. The ideological transition from originally an abangan Islam and NU to Muhammadiyah was because as long as the ngenger were introduced to Muhammadiyah organizations that were tolerant, open, modern, professional, and egalitarian.

Keywords: Ngenger, Ideological Transformation, Muhammadiyah

\section{Introduction}

Based on Javanese philosophy, a person's success in a life career can only be obtained through a learning process from someone successful in their field first. In the Javanese tradition, there is a tradition that is commonly referred to as "ngenger." In the past, this tradition was associated with learning martial arts or supernatural powers, etc. Later on, this tradition shifted to the learning process of intelligence in fields pursued by people by learning from other people who mastered a lot or were smart in their areas. That is why in the past if they wanted to be successful in their career, the Javanese would listen to other people's families with the hope that someday they would be able to follow the success of the people they followed. In a more extreme sense, their relationship is like an employer and a servant, where they must be obedient and obedient. This tradition is depicted in Javanese stories such as Damarwulan, who underwent a ngenger practice to Patih Majapahit, or Jaka Tingkir, who was ngenger at Sultan Trenggana. Later, Jaka Tingkir succeeded in reigning in the Sultanate of Pajang as Sultan Hadiwijaya. Stories like this give inspiration to Javanese people in the village, who want to be successful, to do ngenger (Suratno, et. al. 2018).

The tradition of ngenger is mostly found in East Java and Central Java. In Banyu Biru Village, Tempurejo District, Ngawi Regency, East Java Province in the 1960s and 1970s, many Ponorogo residents chose to ngenger. Of all the children from Ponorogo in the 1960s who ngenger in Ngawi with a poor background and the Nahdlatul Ulama mass organization's ideology or Abangan Muslims. Many are from GP Ansor activists.

Children in the 1960s and 1970s who ngenger in Tempurjo, Ngawi spread to several families. They live together with the family they live in and do their daily work. They are starting from working on the rice fields, helping trade until 
caring for children and cleaning the house and cooking. In the afternoon, they went to formal school at a Muhammadiyah school, which is still alive.

After completing formal education, the children who came to ngenger returned home to Ponorogo. Among them, some who get a couple in the village of Banyubiru, Ngawi. Arriving in Grogol Village's town in Ponorogo, the majority became Muhammadiyah activists and developed Muhammadiyah in Ponorogo. One of the products of people who follow the culture of ngenger is an educational charity: MTs. Muhammadiyah 10 Ponorogo. The people who used to be with other people have now become Muhammadiyah figures. Although some have died, the results of their struggle can be seen with the development of the da'wah and charity education efforts.

In Kurnianingsih \& Brata's (2015) research, the Ngenger tradition was also carried out by the people of Blora Regency. Likewise, with the study of KF \& Sukirno (2016), who researched the Samin indigenous community. Ngenger is performed by the prospective groom or woman while living at the house of the future in-laws. This is considered as a habit of the ancestors and has a useful purpose for the life of people who are about to enter the marriage stage. These objectives include knowing the attitudes and habits of the perpetrator of ngenger, recipient of ngenger and prospective husband or wife, understanding the environment and culture, providing sexuality education before marriage and continuing the agricultural system from generation to generation. However, the Ngenger tradition's implementation has changed due to and following the times so that the Ngenger tradition can exist for the next generation.

This research is different from the research description above, although it is similar in the context of ngenger. That is to live and live with other people. In this study ngenger is related to ideological transformation. This study is also expected to expand and contribute ideas regarding the study of the cadre process and its relationship with local culture in Muhammadiyah today. From this is hoped that activists and leaders of the trust, academics, and the wider community can have sufficient knowledge as capital in deepening the study of Muhammadiyah with the ngenger tradition's object.

From the explanation above, in the tradition of ngenger have are several identified problems. First, the process of teaching Muhammadiyah ideology or cadre strategies carried out to children who have been following the rule of ngenger in Ngawi. This is important to be revealed, considering that there will be a change in the ideology adopted so far in the future. 
Secondly, there is an ideological transformation. Initially, the ideology of NU then moved to Muhammadiyah. In intercultural communication, changes in attitudes, behavior, and romantic views are strongly influenced by the culture and traditions they experience. It is found something new to make it more comfortable or find compatibility with something new.

In this study, the problem that will be revealed about the strategy of planting Muhammadiyah ideology will be limited in the process of ngenger in Ngawi. This is important to disclose the background of changing doctrine. Furthermore, it will be revealed the process of ideological transformation that occurs, starting from the process, steps up to the stability in choosing a new ideology.

\section{Literature Review}

\section{The Ngenger tradition}

Tradition is the similarity of material objects and ideas that originated in the past but still exist today and have not been destroyed or destroyed. Tradition can be interpreted as true inheritance or legacy from the past. However, repeatedly, traditions that occur are not done by accident or deliberately (Sztompka, 2007). According to Hasan Hanafi, tradition is all the past legacies that enter us and enter the current culture. Thus, for Hanafi, tradition, or turats, is a matter of historical heritage and a question of the times' contribution at various levels (Hakim, 2003). From this understanding, whatever is done by humans from generation to generation from every aspect of their life, which is an effort to lighten human life, can be said to be a "tradition," which means that it is part of the culture. More specifically, C.A. van Peursen formulated tradition as a process of inheriting or passing on norms, customs, rules, assets. Traditions can be changed, raised, rejected, and combined with various human actions (Peursen, 1988).

The term ngenger arises when there is a myth by learning from others to achieve rank and social status. Studying here is not in the narrow sense of doing teaching and learning activities in schools, but instead looking for life experiences and learning. (Wicaksono, 2011).

The motives and goals of someone who does the ngenger want to learn the life sciences from the person they made as to the landlady. So they can be more successful in the future as the people they follow. There is research explaining that the tradition of ngenger is a form of child exploitation. A child works with 
a low salary standard and without protection. Then in the future, the word ngenger should be abolished and replaced with workers. This has implications for policies that will guarantee child labor rights (Fakiha \& Haedar, 2015).

In the context of this research, ngenger is a tradition in which young people from Grogol Village, Sawoo District, Ponorogo Regency migrate to Tempurejo in Ngawi to join a family. They live together with the family, eat, drink, and sleep, all of which are borne by the landlady. If it's time for school, then they study in formal school. And after school, they do work in the household. Like shopping, they are going to the rice fields, cleaning the house, or helping trade. In the process of ngenger, these children learn various things. Especially the knowledge gained from the family they live in and also formal schooling.

\section{Ideology Transformation}

In Marx's view, ideology is an idea that is believed to achieve a goal, especially to achieve the undermining of the capitalist system. But, in its development, the doctrine is used for ideas and belief systems or religion. (Ritzer, 2010). Alfian interprets ideology as a comprehensive and in-depth value system of truth and justice in living together in a society. Ideology reflects the most fundamental value order of the value system that lives in the community (Alfian, 1981)

Daczko formulated the transformation concept as a change in an organization's shape, appearance, and structure. In the transformation developed by Daczko, it leads to comprehensive or holistic transformation management. Including changes in people's mindsets. Differences in people's perspectives are an indicator of the effectiveness or success of the transformation program. Also, the transformation program needs to be based on science. This is important not to fall back on indoctrination in assessing the community's response to transformation (Daszko \& Sheinberg, 2005; Siswanto, 2017)

According to Kingsley Davis, social change is changing that occurs in the structure and function of society (Soekanto, 2009). As for Gillin, social changes as variations of the way of life have been accepted either because of geographical differences, material culture, population composition, ideology, or the existence of diffusion or discoveries in society (Soekanto, 2009).

So, socio-cultural changes can be formulated as changes in behavior patterns or attitudes, social interactions, institutions, or cultural structures at a time in society.

From the explanation above, the ideological transformation is a part 
of social and cultural change. Because someone who previously adheres to a specific ideology has taken it to another ideology as a way of life, in this study, the ideological transformation in question is the change in doctrine experienced by children who ngenger in Ngawi in the 1970s from Nahdlatul Ulama', or abangan Islam turned into Muhammadiyah after they followed the ngenger.

\section{Methods}

This study uses a qualitative approach. Perreault \& McCarthy (2006) define qualitative research as a type of research that seeks to dig in-depth information and is open to all responses and not just yes or no answers. The data used is qualitative (data that is not in the form of numbers) (Moleong, 2001). The research strategy is carried out empirically, which investigates a phenomenon in real life by utilizing various evidence sources to answer "how and why" questions. Studies in scientific situations (naturalistic inquiry), using deductive analysis techniques, researchers direct contact with objects, holistic and dynamic perspectives, and researchers as key instruments (Salim, 2006).

Data sources for this study include people and documents. The informants are selected with the maximum variance technique, representing various categories (Sugiyono, 2014). They were chosen from among those who knew, were involved, and were affected by the culture of ngenger, including the following:

1. Traders ngenger the tradition

2. Landlady tradition ngenger

3. Tempurjo Ngawi community leaders who know the process of ngenger

4. The leader of the institution where the education participant ngenger

5. Information in the form of documents, such as photographs, letters, and other documents relating to the ngenger.

In-depth interviews extracted data from informants. Interviews are direct interactions between researchers and respondents to gather expected information and obtain data about respondents with minimum bias and maximum efficiency (Hakim, 2013; Singh, 2002). At the same time, Steward \& Cash (1982) defines interviewing as an interpersonal communication process, with predetermined goals, severe in nature, designed to create interactions that involve asking and answering questions. So in-depth interviews are the process of obtaining information for research purposes using face-to-face question 
and answer between the interviewer and the respondent or the person being interviewed, with or without using interview guidelines, where the interviewer and informants are involved in a relatively long social life, (Linarwati, Fathoni, Minarsih, 2016; Boyce \& Neale, 2006). The interviewees were the actor of ngenger, the landlady as a place to ngenger, and eyewitnesses both in Ponorogo and in Ngawi.

\section{Results And Discussion}

Grogol village is located in the southeast of Ponorogo and includes in the district of Sawoo. The most eastern section because it borders directly with Trengalek district. The town is connected to the north by Besuki village, east by Tugurejo village, west by Ngadisanan village, while a city borders the south with Trengalek district (https://grogol-sawoo.desa.id/peta-desa/)

Some youths from Grogol village who ngenger in Tempurjo or around Ngawi district started from a young man named Maskur to Mrs. Fat, a woman from Tempurjo village, Walikukun District, Ngawi. They married in 1967, and they are still classified as cousins. Maskur is the biological younger brother of Mesir. They had sisters named Dul Majid, Rohmad, and Sajad killed by the PKI during the 1948 PKI rebellion in Madiun. And a younger brother named Zainuri, who was killed by the PKI before the 1965 uprising.

The youths who did ngenger were Asma'un, Murodi, Syamsudin, Tajap, Ahmad, Marwanto, Suparni, Husen, Sudiono, Masrah, Imron, Misnu, Juwahir, Tulus, Jirem, Dullah, Mansyur, Fatonah, Aminah, Fatimah.

\section{The reasons and background of ngenger}

Many of youths in Grogol village, Ponorogo district choose of ngenger can be categorized as follows:

\section{Political conditions}

With the 1948 Madiun Indonesia of Communist Partie (PKI) rebellion, the people around Madiun, including Ponorogo, certainly still remember the PKI atrocities. Many victims, both in Madiun, Ponorogo, and Magetan, fell. Even Kyai Muh Mesir's brother fell victim to the PKI's violence in 1948, namely Dul Majid, Rohmad, and Sajad. They are buried in Bungkal, (interviuw with Murodi, a ngenger person on 24 July 2019). PKI victims are students and Kyais (ulama').

Increased when the PSI and Masyumi parties in 1960 were disbanded 
because their leaders supported the PRRI rebellion. (Roosa, 2008). However, many people in Ponorogo and surrounding areas believed that the Masyumi's dissolution was the insistence and incitement carried out by the PKI to Sukarno.

Then the provocation was carried out by the PKI (Sulistiyo, 2003). Also happened before 1965, at a time in the village of Grogol, there was a wayang kulit (shadow play). The mastermind behind the performance was suspected of having been infiltrated by the PKI. When the puppeteer said, "bismillah ....kool kobis miediolah (processed noodles), qulhu ... sekul tahu (tofu rice)". At that time, Asma'un and the Grogol village youth were angry and broke up the puppet show. Even the puppeteer gets hit in the mouth (tabok), (Interview with Amat, a person of Ngenger, on 22 July 2019).

Many scientists and historians consider that the PKI is a party that has a cadre strategy, political education, and qualified political agitation. To the extent that many arts and cultural associations were co-opted and infiltrated by the PKI. In Ponorogo itself, there are shadow puppets, shadow puppets, kethoprak, ludruk, gambyong not escape from PKI ideology infiltration.

Sidiq, Muh Mesir, Askiram, and Manskur were even angrier when Muh's Mesirian brother and Maskur named the PKI killed Zainuri before the PKI rebellion in 1965, which made them determined to provoke children in the village of Grogol to study with ngenger in Ngawi. He hoped that equipping young people with a holistic understanding of religious knowledge in the future would directly stem the growth of PKI sympathizers. Besides, it is also to develop Islamic da'wah in Grogol in particular and Ponorogo in general, where the majority were abangan community. The process of ideological transformation in social change is a response to a complex cultural transformation. Change has a very broad meaning, which concerns changes with the social system and involves changes in interaction dimensions between individuals (Guntoro, 2020).

\section{Educational conditions}

Grogol villagers in the 1960s were rural communities located about $25 \mathrm{~km}$ southeast of the town of Ponorogo. The area is far from the city center, and infrastructure is still minimal. They are mostly laying people with little education. Although there are Gontor and Tegalsari boarding schools, schools are a luxury item. Only for people who rich or have the 
steel to do it.

At that time, the Grogol village youth had received primary education or SR (community school); for further instruction, they only relied on nonformal education in the Bopong hamlet. In the afternoon, they studied the Al Qur'an in the langgar (mushola), which was taken care of by the village clerks, namely Muh Mesir and Askiram Boarding school Gontor alumni and Sidiq Boarding school Tegalsari alumni. Seeing the community's education and welfare condition, the Grogol village youths were encouraged by Muh Mesir, Sidiq, and Maskur to ngenger in Ngawi. Besides, one of them is caused by education in Ponorogo, far from Tegalsari and Boarding school Gontor. On the other side, education in these two places is considered expensive. However, they are needed by parents to help their daily activities in the fields. Many young children are banned from school and asked to help their parents by working in the fields, farm laborers, and caring for livestock by looking for grass in the forest.

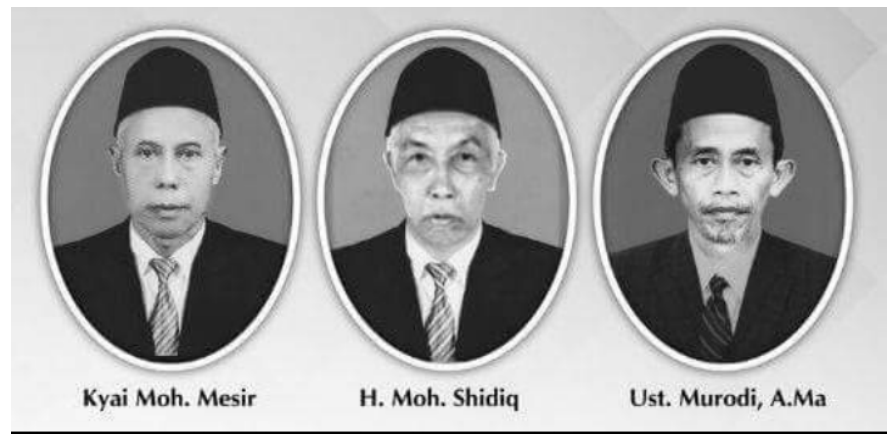

Picture: from leaft is Muh Mesir, Sidik dan Murodi

No less significant is the progress and progressiveness of the Muhammadiyah education institution in Tempurjo, Ngawi. At that time around the famous and reputable Ngawi college. So many students from various regions who study. There are thousands of students who attend formal or diniyah school. There is a commute, mondok and there is also a ngenger. Seeing this condition Muh Mesir, Sidik and Askiram encouraged young people to listen while going to Tempurjo, (Interview with Maskur, a landlady person at 13 June 2019).

Educational background as a reason for someone to ngenger was Sari Handayani in her thesis in 2014 in RT 5/RW 36, Babadan Hamlet, 
Sendangtirto, Berbah, Sleman (Thesis, Kisah dua keluarga dalam Ngenger: 2014 ) the main reason someone ngenger about education is that he wants to learn formally for free. One of the reasons that Grogol youths ngenger is that access to education in their hometowns is challenging to reach, both geographically and economically. Hence, they choose to ngenger so they can go to school while working. Here there is a symbiosis of mutualism, that children can get an education and fulfill their daily needs. In contrast, the landlady gets people who will help with their work or household activities.

Likewise, with the results of Sri Suharti's research from the Faculty of Cultural Knowledge at UI in 2010 on the book titled "Ngenger in the Anteping Tekad novel" written by Agnes Suharti with the publisher Balai Pustaka in 1957. The results explained that the main character in the "anteping tekad novel" named Indiah following the tradition of ngenger to the family of Mrs. Sutarno. Indiah does Ngenger because he believes that education will be better and will succeed if pursued by ngenger. Since Indiah is a junior high school graduate, she wants to learn two things with a low level of education. First, learn from the difficulties experienced during ngenger, such as being insulted, humiliated, and under inner-pressure. Then know how life, manners, and also ethics are in a higher social class.

\section{Economic conditions}

The majority of Grogol villagers are farm laborers, farmers who work on other people's land. Because a handful of certain rich people only owns the land. The planting period in one year can be done three times. Usually, agricultural land is planted with rice, but only twice a year because it relies on rainwater. At the same time, the third planting period is if farmers can finance irrigation with crops like soybeans, corn, or green beans. But if you do not have it will be left.

In the 1950s and 1960s in Indonesia, the Javanese term called paceklik. Namely, the difficult economic conditions that affect the scarcity of food. This is compounded by the pagebluk (Condition many diseases that attack the community) season. Several factors influence this. Among them is politics first. Political conditions at the elite level penetrated the grassroots tensions resulting in upheaval in the regions. There was a clash between communists and Islamists, which sometimes caused stress. Uncertain political conditions due to the Islamists' friction with the communists resulted in an unstable political condition that affected the 
increase in prices, especially food. Besides, the corrupt bureaucracy and foreign debt that accumulated due to the construction of a symbolic giant project (Sulistiyo, 2003)

Second, crop failure's deteriorating economic conditions are exacerbated by rat pests and poor agricultural infrastructure. They are so increasing the poverty and suffering of the people. According to Marwanto, (Interview with Marwanto, a ngenger person on 10 July 2019), he had to go to school in the afternoon, while in the morning, he became a farm laborer. Even though his family has enough land to support his family and eight siblings, if the harvest is good enough. Because farming conditions cannot be relied upon, they eat rice daily with tiwul (rice from cassava) with vegetable lompong and heart banana (ontong). The intention and will to build goodness and prosperity are essential in pushing for civilization's stages by improving its quality, which is always carried out for humans' good and well-being (Kistanto, 2018).

By the views of Ila Fakiha \& Haedar (2015), the motivation of youth ngenger to the kiyai can be categorized in two ways: cause motives and purpose motives. The causes reasons are as follows: economics, studying Sufism, studying Suwuk (Martial art with magic), and changing the village community's state. While the reason for the goal: restrain the passions, near the kiyai, seek knowledge and study of religion, and become a kiyai.

The people of Grogol village, Ponorogo who ngenger to Ngawi, certainly do not want to study Suwuk, Sufism, or become a religious teacher. But the impoverished Grogol village community's economic conditions encouraged young people to ngenger so that they could continue their lives. Thankfully, they were able to learn for free and were able to change themselves and society.

\section{Socio-cultural conditions}

As a village in general, including the town, Grogol is still very thick with Javanese culture, and its people's life and culture are still very traditional. Electricity in the village only came in 1990. So in 1960-1975, lighting always used kerosene lamps with energy sources derived from kerosene. Even then, if the community can buy or stock is still available at the grocery shop. There are still many traditions of heritage that smell syncretism, superstition, and khurofat, (Stories that are composed or fabricated related to natural events or beliefs). Nyadran (Go to a place that 
is considered sacred to pray for something, like asking for a blessing, asking for a mate and asking for wealth) culture in sacred places is often done by the community. Even when there are still many celebration offerings in every corner of the house, he said it was for the ancestors' spirits and as food for souls to not interfere with the celebration. The village's religious system usually consists of a balanced integration between elements of local culture and Islam. A form of syncretism in a society which is an actual folk tradition. The religious traditions of the Abangan are mixed with many ritual feasts and are a complicated, broad, and complex belief system. (Jinan, 2015).

Generally, Javanese people, especially the Grogol village, have traditions and cultures that are still firmly attached. This is one of the factors influenced by Mataraman (Mataraman is used to refer to a region of the former kingdom of mataram Islam) culture. In Grogol village, reog, shadow puppets, ketoprak, ludruk, gajah-gajahan, jaran thik, and gambyong are still found. The event was held to celebrate both the village government and individuals' celebrations, such as marriage, circumcision, and ruwatan (Performing wayang kulit art in the morning to keep away from crime and misfortune), (Kurnianto, 2015).

Almost certainly, during the celebration and there was a show of alcoholism. They feel satisfied when they are drunk and unconscious. Besides, in the reog performance, gajah-gajahan and jaran thik, many of the actors were possessed by possessed performances. The public will be more enthusiastic about watching the show if someone is possessed. According to them, the show has strong magical power. Perpetrators are usually unconscious, eyes bulging, howling, rolling up to eat strange things. Such as leaves, soil, until glass. It is almost certain that each art performance will begin, so a shaman will overwrite the tools by burning incense and sprinkling flowers. That is done to invite spirits, jinn, or ghosts.

Ponorogo Regency is famous for having Reog artistry, including the village of Grogol. Reog is an art that is said to be inspired by an event in a Bantarangin kingdom. In the art of Reog, there are several components such as accompaniment music, dadak made from Peacock, jathilan, warok, bujang ganong. Single women now perform as Jathil dancers. It used to be done by a single boy who had a handsome face. And most of the jathil are taken care of by warok to be their life partners and sleeping partners. This is called gemblakan. Though warok already has a wife. After they did not 
become jathil, becoming the gemblakan also ended (Mukarromah \& Devi, 2012).

The processes inherent in tradition and the arts such as drunkenness, possession, sending offerings, gemblakan, and shamanic practices are assessed by young people who are enlightened because of Gontor education such as Muh Mesir, Askiram, and Maskur contrary to Islamic creed, so they must be removed. In addition to opposing the Islamic ideology, the activity also has a high destructive power on society. Moreover, many of these arts have been infiltrated by the PKI movement. One way to eradicate the traditions that destroy the skills is to educate young people and cadre them as preachers and community leaders.

This is the purification movement towards understanding doctrine and implementing sharia. According to Peacock, which is, in essence, an urgent need to protect orthodoxy from various influences from outside of Islam, both in the form of mysticism, magic, animism and other forms of syncretism are unconsciously incorporated into Islamic doctrine. Only by refining the understanding of this doctrine can Muslims grasp the rationality of aspects of modern life today (Peacock 1978). On the other hand, Nakamura emphasized that many of the people who came from the abangan community were interested in becoming santri, moving towards the actual practice of Islamic teachings. (Nakamura, 2017). This is certainly different from NU, which has a powerful nuance of cultural preaching, making culture a medium for preaching (Alhidayatillah \& Sabiruddin 2018). However, the process of ideological transformation in Ngawi is different from that of Solikhul Huda's thesis, which examines the shift in the ideology of Muhammadiyah in Islam. Many Muhammadiyah cadres have become FPI activists because they think FPI is more assertive in eradicating evil. What happened in Ngawi went soft and is still in the context of moderate Islam (Hidayat, 2019).

\section{Ngenger activity}

The youth during ngenger, usually do activities such as household activities. They were starting from cleaning the house, cooking, helping in the fields, shopping, and trading. Adapted to the profession and family occupation lived. Even to take care of children or grandchildren, if the landlady has it. 


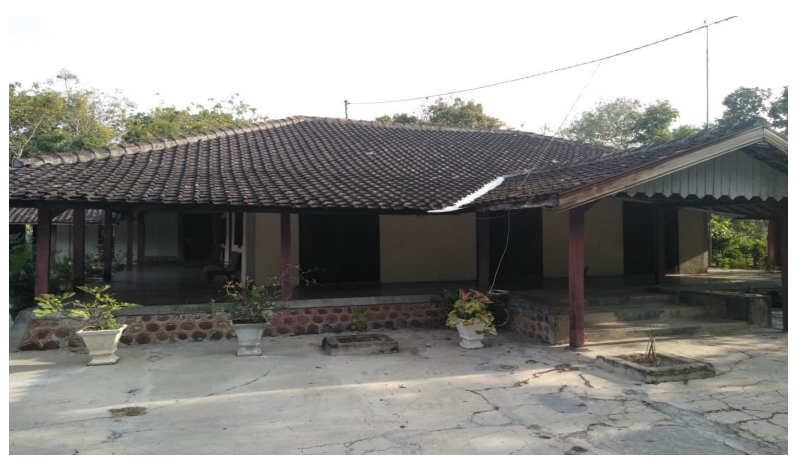

Picture: Anwar's house as a location to ngenger is still original

Young men who ngenger don't feel burdened even though their work is both rough and heavy. This happened because they were accustomed to a difficult life in their hometown. On the other side, they realize that it has become a consequence if they work hard to help their landlords and not relax as a young man who joins others. Besides, young people's ngenger feel that their lives are supported by going to school for free.

Usually in the morning young people who hear help their families with their homework. While in the afternoon they go to school or madrasah to study.

\section{The process of regeneration and planting of Muhammadiyah's Ideology during Ngenger}

The regeneration process in the ngenger tradition in Tempurjo, Ngawi, can be classified into 3. Namely, in the family, at school or madrasah, and the third in the environment. The categorization of these three domains is because young people who ngenger interact in these three social spaces. And all three have a stake in influencing the views and ideology of the ngenger.

\section{In the family}

The families where they ngenger the majority are wealthy people with large of farmland and local community leaders. The land they own is usually measured on a bau scale. One bau is equal to 7,000m. Even Maskur's in-laws have a land area of $90 \mathrm{bau}$. That is $90 \times 7,000 \mathrm{~m}$. Then some figures become traders. Also they also many who work as PNS(government employees) teachers.

Even though Tempurjo village is far from urban areas, its citizens have an open mind and modern outlook. Young people who ngenger are 
given the freedom to learn, think, and organize. They were even encouraged to advance Muhammadiyah education in Tempurjo by activating official student activities under the local Muhammadiyah educational institution but not Muhammadiyah orthodontics. At that time, the Muhammadiyah Orthom(Ortom is short for autonomous organizations. Which is the official wing of the organization in Muhammadiyah) activity was not yet established in Tempurjo. But every action has the ideology of Muhammadiyah (Interview with Sudiono, a Ngenger person, on 14 June 2019).

From some of the young people who ngenger, most of them live in six families. Namely the Maskur, Anwar, Rofii, Furqon, Sarkowi, and Syam families. According to Ms. Anwar, even though their family adheres to NU organizations, her husband, Mr. Anwar, is an administrator of the Muhammadiyah Tempurjo college and his siblings and other community leaders. Anwar's family gave independence in learning. Their family never forced them to enter and be active in any of the mass organizations. What is essential for them as the landlady is to ngenger homework and rice fields are completed and care for them properly, encouraging them to learn religion to the fullest. The landlady's family feels it has satisfaction if it can care for the poor's children and send them to school. Especially if one day they become successful people. They hope that if they go home, they will always keep in touch (silaturahmi) (Interviuw with Mrs. Anwar, the landlady of ngenger at 16 July 2019).

This is also done in other families such as Maskur, Syam, Rofii, Furqon, etc. As community leaders, managers of Muhammadiyah schools, religious teachers, and Muhammadiyah administrators, $\mathrm{H}$. Sarqowi and $\mathrm{H}$. Rofii always emphasized studying. Especially religion. Because with a good understanding of spiritual knowledge, civilization will advance and develop well.

Besides that, Maskur also said that community leaders, both as teachers and landlady, always give role models for life. Maskur will be angry if the children who ngenger to his house don't read the Al Qur'an, don't pray, or don't study.

One day, H. Rofii finished teaching, then left in the evening by riding an onthel bicycle to fill in the recitation. But on the dark road, H Rofii fell and entered the river. His students heard sounds like objects falling in the river near their hostel, hurried towards the place. Seeing H Rofii fall, they immediately helped him and advised him to go home and rest. But H Rofii 
immediately headed to his bicycle and continued his journey to fill the recitation (Interviuw with Maskur, a landlady person and teacher at 13 June 2019).

Children who ngenger and also students who hear the incident touched his heart. By riding a bicycle and physical conditions are not right because of falling but have a persistent spirit in the fight for religion. To implement a new cultural value, an example is needed from the leaders who are usually used as role models to follow and imitate what other people do concerning cultural values (Perbawasari \& Setianti, 2013).

\section{In the Environment}

The Ponorogo youth who ngenger were originally ordinary people or Muslim abangan, and there were also the officials of GP Ansor, who first learned about Muhammadiyah in Tempurjo Ngawi. The regeneration of Muhammadiyah takes place so that children ngenger that Muhammadiyah is an open and not rigid organization. This can be seen that Muhammadiyah in Tempurjo, Ngawi has a Charity in Educational Efforts, where are several people affiliated with $\mathrm{NU}$, besides that there are no doctrinal activities which force them to make sympathetic young people from Ponorogo.

Educational figures and the community in Tempurjo are welleducated and open-minded people. Among them is Ropii, Maksum, Sarqowi, Anwar, Maskur. The model does not impose the will to adhere to an ideology and does not demand uniformity of doctrine, especially Muhammadiyah. They can live side by side even though they are still one family but differ in ideology. For example, Mr. Maskur is a Muhammadiyah figure while Mr. Anwar, his brother-in-law, is a NU person. But they are administrators of Muhammadiyah schools and are equally promoting education in their father's land waqf, (Interviuw with Suparni, a ngenger person at 20 July 2019).

Tempurjo peoples have very high religious awareness. Every religious event and activity at school always gets support from the community, such as funding and building schools. Even when the school from Ponorogo brought students and people together to watch, it was very lively.

Based on the Social Construction Theory of Reality put forward by Berger and Luckman. The perpetrators of ngenger experience internalization, individuals, absorb the values socialized by their environment, but not all values can be absorbed entirely. On this basis, individuals can interpret 
reality with their version, which they consider to reflect objective reality (Berger \& Luckmann, 1966).

\section{At the madrasa diniyah}

The curriculum at the Muhammadiyah Tempurjo College has two educational models. In the morning, a formal madrasa school teaches general subjects and religion. While in the afternoon, there is a madrasa diniyah that specializes in teaching theology. Religious knowledge is taught various kinds, ranging from Arabic, fiqh, interpretation, hadith, mantiq, nahwu shorof, and of course, reading the Qur'an and the kitab kuning (yellow book). But there are no subjects at all, Muhammadiyah science. Likewise, with the ortom Muhammadiyah activities, there are also none. There is a student organization like the student council.

In every learning process, especially madrasa diniyah in the afternoon, teachers teach Islam as generally. But there are essential things in the learning process. Teachers and administrators have a high dedication to teaching. They are professional, competent, and also open to teaching Islam. Islam is not exclusive and is very moderate. They gave many examples of the first figures of Muhammadiyah who fought for the nation and state. Like Ahmad Dahlan, General Sudirman, Mas Mansyur, Kasman Singodimejo, Ki Bagus Hadikusumo, Hamka, and even Sukarno (the first president in Indonesia) were also Muhammadiyah teachers.

Teachers, caregivers always emphasize the importance of being earnest in carrying out Islamic da'wah. Selfless and full of struggle. Many tests and challenges are specific, but they must be carried out.

The authority and religious environment created were very strong in the Tempurjo Muhammadiyah college complex at that time. Many religious activities are made, such as Islamic holidays, student endings, and student contests, so that students' character is formed very strongly to express Islamic values.

As agents in planting values, educational institutions can provide value in the form of knowledge, attitudes, and skills needed by society. Furthermore, when viewed from Van Peursen's theory of cultural development, it is hoped that educational institutions can position themselves as a functional stage. Educational institutions, as agents of value transformation, must provide values shared by society (Az-Zafi, 2017). In carrying out the process of civilizing values so that they are formed into 
characters, Pierre Bourdieu can use the opinion of Habitus. Educational institutions can carry out habituation through several activities. Habituation can be done through social interaction, maintained with the control exercised by academic institutions (Bourdieu, 1996).

\section{Ideology Transformation Process}

Sigmund Freud explained the theory of religious or ideological transformation, then the father or parent factor was huge in the process of change (Samiun, 2006). Likewise with young people who ngenger in Ngawi. They are far from biological families, so when the landlady ngenger, the caregivers, teachers, and community leaders are certainly their parents who will influence the child's thoughts and attitudes to ngenger.

The following is a list of names that understand and have ideological changes.

\begin{tabular}{|c|c|c|c|c|}
\hline Name & $\begin{array}{l}\text { Years of } \\
\text { ngenger }\end{array}$ & $\begin{array}{l}\text { A background } \\
\text { and cause of } \\
\text { ngenger }\end{array}$ & $\begin{array}{l}\text { Idiology after } \\
\text { ngenger }\end{array}$ & Information \\
\hline Asma'un & $1963-1968$ & NU/economy & Muhammadiyah & \\
\hline Murodi & $1963-1968$ & NU/economy & Muhammadiyah & \\
\hline Syamsudin & $1963-1968$ & Abangan/economy & Muhammadiyah & \\
\hline Tajap & $1970-1975$ & $\begin{array}{l}\text { Abangan/ } \\
\text { Pendidikan }\end{array}$ & MuhammadiNU & $\begin{array}{l}\text { Join Mu- } \\
\text { hammadiyah } \\
\text { community } \\
\text { organizations } \\
\text { but also still } \\
\text { follow NU } \\
\text { tradition be- } \\
\text { cause of the } \\
\text { environment }\end{array}$ \\
\hline Ahmad & $1960-1968$ & NU/economy & NU & $\begin{array}{l}\text { It remains } \\
\text { NU because } \\
\text { I got in-laws } \\
\text { from NU }\end{array}$ \\
\hline Marwanto & $1968-1973$ & NU/ Education & Muhammadiyah & \\
\hline Suparni & $1968-1973$ & NU/ Education & Muhammadiyah & \\
\hline
\end{tabular}


Ngenger tradition and ideology transformation ... (Anang Masduki, Dani Fadillah, Fajar Dwi Putra)

\begin{tabular}{|c|c|c|c|c|}
\hline Name & $\begin{array}{l}\text { Years of } \\
\text { ngenger }\end{array}$ & $\begin{array}{l}\text { A background } \\
\text { and cause of } \\
\text { ngenger }\end{array}$ & $\begin{array}{l}\text { Idiology after } \\
\text { ngenger }\end{array}$ & Information \\
\hline Kusen & $1970-1975$ & NU/ Education & $\mathrm{NU}$ & $\begin{array}{l}\text { Ngenger in } \\
\text { Mbrejing }\end{array}$ \\
\hline Sudiono & $1975-1983$ & $\begin{array}{l}\text { Abangan/ } \\
\text { Education }\end{array}$ & Muhammadiyah & \\
\hline Masrah & $1975-1978$ & Abangan/economy & Muhammadiyah & \\
\hline Imron & $1970-1975$ & NU/economy & Muhammadiyah & \\
\hline Misnu & $1963-1968$ & Abangan/economy & $\mathrm{NU}$ & $\begin{array}{l}\text { Ngenger in } \\
\text { Mbrejing }\end{array}$ \\
\hline Juwahir & $1968-1973$ & $\begin{array}{l}\text { Abangan/ } \\
\text { Education }\end{array}$ & $\mathrm{NU}$ & $\begin{array}{l}\text { It remains } \\
\text { NU because } \\
\text { it disappoint- } \\
\text { ed with Mu- } \\
\text { hammadiyah }\end{array}$ \\
\hline
\end{tabular}

\begin{tabular}{lllll}
\hline Tulus & 1968-1973 & NU/ Education & Muhammadiyah & \\
\hline Jirem & 1970-1975 & NU/ Education & Muhammadiyah & \\
\hline Dullah & 1968-1973 & $\begin{array}{l}\text { Abangan/ } \\
\text { Education }\end{array}$ & NU & $\begin{array}{l}\text { It remains } \\
\text { NU because } \\
\text { of the } \\
\text { environment }\end{array}$ \\
\hline $\begin{array}{llll}\text { Fatonah } \\
\text { (Sipat) }\end{array}$ & 1970-1975 NU/economy & Muhammadiyah & $\begin{array}{l}\text { Cultural and } \\
\text { simpathisan }\end{array}$ \\
\hline Aminah & 1970-1975 NU/economy & NU & $\begin{array}{l}\text { It remains } \\
\text { NU because } \\
\text { of the } \\
\text { environment }\end{array}$ \\
& & & &
\end{tabular}

Ms. 1970-1975 NU/Education Muhammadiyah

Fatimah

(Fat).

Suroso 1970-1973 Abangan/economy Muhammadiyah

If you look at the data above, it can be concluded that $80 \%$ of young people who ngenger in Ngawi experience a change in ideology from NU and Nationalists to Muhammadiyah. However, there are around 20\% who are still 
affiliated with NU. In Abdul Munir Mulkhan's view, Muhammadiyah in rural areas can be classified into four types. Namely, Al Ikhlas, Kiyai Dahlan, MuNU, and Marmut (Mulkhan, 2000). Al Ikhlas is a Muhammadiyah group whose totality purifies Islam. The Kiyai Dahlan group is a purely Islamic group that does not work alone but is tolerant of TBC (Takhayul, Bid'ah, and Churofat), $\mathrm{M} u \mathrm{NU}$ is a Muhammadiyah group that still maintains TBC with (NU tradition in religious) tahlilan, yasinan, mitoni, slametan and various religious traditions, the last being Marmut groups or Muhammadiyah Marheinis. They see many secular and syncretic lives.

The sociological and geographical conditions in Grogol Village, Ponorogo, are the same as Abdul Munir Mulkhan's description, namely rural communities and farmers. However, researchers found differences in the Muhammadiyah variant. The youth who ngenger had a nationalist or abangan background and NU. After ngenger about Tempurjo, Ngawi's transformation did not become MuNU or Marmut. But the groups of Kiyai Dahlan and MuNU Nobody is Marmot. Even though they and their families came from nationalists or abangan, as long as they ngenger, planting religious values and striving to uphold religion are imperatives that have become ingrained. The $\mathrm{MuNU}$ variant was found not merely because of the ideological understanding cultivating religious attitudes with cultural traditions. Instead, it was due to maintaining the NU environment's moods or feelings or because their families were NU fanatics.

On the other hand, Nahdltaul Ulama, as a traditional Islamic organization, is indeed more attractive to rural groups than urban areas. This shows that the indigenization of Islam has an urgency for social-societal dynamics. Traditions that need to be developed within NU for the present and future interests are a paradigmatic step of meaning. Because a transformation, both thought and social, must move on and draw inspiration from tradition. So, efforts are needed to explore the tradition that can support transformation (Hartati \& Hambali, 2018).

The varieties of religious experience by William James explained two factors that influence ideology changes: family factors that occur at any time of interaction. The second is due to individual personality. Namely, the attitude of seeing, feeling, and experiencing an event then appears internalization of the event witnessed or experienced into each of them (Jalaludin, 2009).

According to Kiyai Delan, a Tempurjo Muhammadiyah teacher, neither teachers, community leaders, Muhammadiyah administrators, and the landlords 
would ever ask, give doctrine to enter and be active in Muhammadiyah to the ngenger child. Muhammadiyah lessons also did not exist at that time. So it can be said that Muhammadiyah leaders and the Tempurjo community are very open in their thought and egalitarian behavior. Maskur added that the Muhammadiyah ideology process entered through daily interactions without being said only through everyday attitudes expressed by the management, community leaders, and education managers of Muhammadiyah Tempurjo. In the intellectual view, it is called transformative pedagogic epistemology. Namely, a pedagogic that develops according to social change dynamics and individual development is continually changing. Thus transformative pedagogy is dynamic pedagogy. The transformation process's starting point is a creative individual (Fauzi, 2018; Tilaar, 2012). Several factors make most of the children who ngenger when they come back to their villages choose to change their ideology from NU to Muhammadiyah.

First, feel sympathetic with Muhammadiyah when they heard that between 1960 and 1970, Muhammadiyah college in Tempurjo was very advanced, lively, and progressive. Many good students go to school, commute, and ngenger. This situation makes the hearts and minds of children ngenger that Muhammadiyah is a large, modern, excellent, and advanced organization. Besides being open, egalitarian, and not imposing Muhammadiyah ideology, it makes children who ngenger sympathetically.

Second, community leaders, administrators, and caregivers of Muhammadiyah Tempurjo colleges have high dedication and sincerity. So that the child ngenger feels touched his heart to see the honesty. They saw Muhammadiyah leaders acting wholeheartedly for the sake of Islamic da'wah. Not concerned with the material, actually dare to sacrifice for the progress of Islam.

Third, the emphasis made by the landlady, community leaders, and caregivers of the Muhammadiyah Tempurjo College on the importance of religious knowledge, a solemn obligation to preach Islam, makes those who are called to call for jihad to develop Islamic propaganda. They realize that Islam is part of life, a guide to the truth, so it must be fought with all your heart. Even need sacrifice, good energy, mind, treasure until the time, for the sake of getting the pleasure of Allah SWT.

The main factor that caused $20 \%$ of them to remain NU was because they returned to the neighborhood with a very fanatical NU environment. Most of them live in the hamlet of Bopong and Karangjati, Grogol village. There 
were two very fanatical figures there. In Bopong, Muh Mesir (Maskur's older brother) was a NU chaplain and founded MI Nurul Huda. While in Karangjati, there was H. Kasanun who founded MTs Ma'arif. These two figures became the driving force of NU's activities. Some people like Amat, Misnu, Juwahir, and Aminah are in that environment so that if they have a different ideology, they feel uncomfortable because they are afraid of being ostracized. But three people are in the village of Bopong persistently defending the doctrine of Muhammadiyah, namely Syamsudin, Imron, and Murodi.

Other causes continue to choose NU because of marrying a fanatical family of NU. Like Amat in Karangjati, who became the son-in-law of an NU chaplain. Amat feels uncomfortable if she has to be different from her parentsin-law's extended family, mostly since Amat lives with her parents-in-law.

\section{Post-Ngenger}

Social changes, according to Sambas (2016), have the characteristics of which there are continuous changes, followed by other social changes, resulting in temporary disorganization as adjustment. The Grogol youth who ngenger in Ngawi then returned home. They initially joined NU mass organizations, most of them turned into Muhammadiyah. The ideology of Muhammadiyah that they have just adopted after ngenger to it survives until now. Then, organizationally they have a new culture that is more familiar with the characteristics of Muhammadiyah, including a sound system, good management, and orderly organization. In terms of worship, if previously, when holding Eid al-Fitr or Eid al-Adha prayers in the mosque, after ngenger to them, they have the feast of worship on the field that lasted until now. Also, they established a charity effort to develop Muhammadiyah, namely five mosques, nine small mosques, educational institutions MTs Muhammadiyah 10 and 3 of TK ABA (Kindergarten of Muhammadiyah).

One of the prerequisites for cultural change is the guarantee of good relations with the environment, communication, division of roles, and socialization (Kaplen, 2002). In the context of the ideological changes that occur in young people after ngenger, they also consolidate and also share the role of intense communication and communication in the Muhammadiyah community that they have just run. Also, massive socialization took place. The feast of prayer in the field, doing the round takbir and consolidating recitation of prayer.

The village of Grogol, which was initially the majority of NU, after the 
youths' ngenger of in Ngawi, formed the Muhammadiyah branch management. So that Grogol village is divided into two. In the north are NU residents, and in the south are Muhammadiyah residents. The north is centered on the family Muh Mesir and Maskur. The south is centered on the south of Mount Gempeng. In this place, MTs Muhammadiyah 10 Ponorogo was established.

Some young men used to ngenger that Tempurjo had died, and most were still alive. Those who are still alive continue to develop Muhammadiyah by reviving branches and twigs and managing Muhammadiyah's business charity. For those who have died, their children's preaching struggle for Muhammadiyah is continued. There were four children from one of the youths who used to ngenger to the PDM (district leaders of Muhammadiyah) secretary, the PWM (Province leaders of Muhammadiyah) Deputy secretary, the PCM (district leaders of Muhammadiyah) chairman, and the PDPM Kokam (district leaders of Young Muhammadiyah) commander.

\section{Conclusion}

The cause of ngenger is the poor condition of the people, the onslaught and rebellion of the PKI, and the far access to education made the youth of Grogol village, Ponorogo. East Java determined to be able to go to school for free. The trick is to ngenger. In addition to these reasons, it is also to equip youth with religion to compete and offset the PKI movement's pressure. The Muhammadiyah regeneration process took place in a way. First, they saw Muhammadiyah as an open and not rigid organization. This can be seen that Muhammadiyah in Tempurjo, Ngawi has a Charity in Educational Efforts, which has several people affiliated with NU. Apart from that, no doctrinal activities are compelling. So the attitude of the Muhammadiyah leadership in Tempurjo made sympathetic young people from Ponorogo. Second, the families where they ngenger the majority are wealthy people with large land and local community leaders. They are given the freedom to study, think, and organize. They were even encouraged to actively advance Muhammadiyah education in Tempurjo by activating official student activities under the local Muhammadiyah educational institution. Third, the exemplary of educators and community leaders who have sincerity, the spirit of struggle, and the doctrine of the emphasis on the importance of Islamic da'wah. The ideological transition from the original Islamic abangan and NU to Muhammadiyah was because, during their ngenger, they were introduced to Muhammadiyah organizations that were tolerant, open, and egalitarian. But this was tested when they returned 
home to the village of Grogol. At that time, there was an NU Masyumi alumni organization. Some uphold the ideology of Muhammadiyah, some are halfhearted, but some are returning to NU. Those who returned to NU were due to environmental factors, which were the majority of NU, they felt uneasy if they became a minority. But there are also even though their minority still hold fast to Muhammadiyah.

\section{References}

Alfian. (1981). Kebudayaan, dan manusia Indonesia. LP3ES.

Alhidayatillah \& Sabiruddin. (2018). Nahdatul Ulama (NU) dan Muhammadiyah: Dua wajah organisasi dakwah di Indonesia. Al-Imam Jurnal Manajemen Dakwah. 1(1), 9-16. https://ejournal.uinib.ac.id/ jurnal/index.php/alimam/article/view/53.

Az-Zafi, A. (2017). Transformasi budaya melalui lembaga pendidikan. Sosiohumaniora, Jurnal Ilmiah Ilmu Sosial dan Humaniora. 3(2), 105-112. doi: $10.30738 /$ sosio.v3i2.93.

Berger, P. L., \& Luckmann, T. (1966). The social construction of reality, the treatise in the sociology of reality. Doubleday. http://perflensburg.se/Berger\%20 social-construction-of-reality.pdf

Bourdieu, P. (1996). Distinction: a social critique of the judgment of taste. Harvard University Press.

Boyce, C., \& Neale, P. (2006). Conducting in-depth interviews: A guide for designing and conducting in-depth interviews for evaluation input.

Daszko, M., \& Sheinberg, S. (2005). Survival is optional: Only leaders with new knowledge can lead the transformation. Transformation, 408, 247-7757.

Fakiha, I., \& Haedar, M. A. (2015). Makna santri ngenger di boarding school Pesantren Sunan Drajat. Jurnal Paradigma. 3(2), https://jurnalmahasiswa. unesa.ac.id/index.php/paradigma/article/view/11279

Fauzi. (2018). Peran pendidikan dalam transformasi nilai budaya lokal di era millenial. Insania. 23(1), P. 51-65. https://doi.org/10.24090/insania. v23i1.2006

KF, I. F., \& Sukirno, T. (2017). Perkawinan masyarakat adat Samin di Desa Klopoduwur, Kecamatan Banjarejo, Kabupaten Blora setelah berlakunya 
Undang-undang Nomor 1 Tahun 1974 Tentang Perkawinan. Diponegoro Law Journal, 5(4), 1-10. https://ejournal3.undip.ac.id/index.php/dlr/ article/view/15757.

Guntoro. G. (2020). Transformasi budaya terhadap perubahan sosial di era globalisasi. Jurnal Asketik: Agama dan Perubahan Sosial. 4(1), 22-33. https://doi.org/10.30762/ask.v4i1.2122.

Handayani, S. (2014). Cerita dua keluarga di dalam budaya ngenger: Di RT 5/RW 36, Dusun Babadan, Sendangtirto, Berbah, Sleman. (Doctoral dissertation, Fisipol UGM Jurusan Pembangunan Sosial dan Kesejahteraan dh. Ilmu Sosiatri).

Hakim, L. N. (2013). Ulasan metodologi kualitatif: Wawancara terhadap elit. Aspirasi: Jurnal Masalah-Masalah Sosial, 4(2), 165-172. https://doi. org/10.46807/aspirasi.v4i2.501

Hakim, M. N. (2003). Islam tradisional dan reformasi pragmatisme, agama dalam pemikiran Hasan Hanafi. Bayu Media Publishing.

Hartati \& Hambali. (2018). Transformasi NU di Indonesia: Upaya menghilangkan polemik di tengah perubahan politik. Substantia: Jurnal Ilmu-ilmu Ushuludin. 20(1), 35-48. http://dx.doi.org/10.22373/ substantia.v20i1.3404.

Hidayat, M. C. (2019). The clash of ideology Muhammadiyah (Moderate versus radical ideology fight). Jurnal AFKARUNA. 15(2), 328-333. https://doi. org/10.18196/AIIJIS.2019.0108.328-333

Jinan, M. (2015). Muhammadiyah studies: The transformation of research on Islamic movement in Indonesia. Analisa: Journal of Social Science and Religion. 22(2), 269-280. http://dx.doi.org/10.18784/analisa.v22i2.96.

Kaplen, D. (2002). Teori budaya. Pustaka Pelajar

Kistanto, N. H. (2018). Transformasi sosial-budaya masyarakat Indonesia. Sabda: Jurnal Kajian Kebudayaan. 13(2), 169-178. https://doi.org/10.14710/ sabda.13.2.169-178.

Kurnianto, R. (2015). Nilai-nilai budaya ponoragan dalam konteks kekinian. Conference: Konggres Budaya Jawa Timur. https://www.researchgate. net/publication/323794635_Nilai-Nilai_Budaya_Ponoragan_dalam_ Konteks_Kekinian_1_Oleh_Rido_Kurnianto_2.

Kurnianingsih, Y. S., \& Brata, N. T., (2015). Tradisi ngenger dalam konteks bride service pada masyarakat Jawa di Desa Botoreco, Kecamatan 
Journal of Social Studies (JSS), Volume 17, Number 1, 2021: 37-64

Kunduran, Kabupaten Blora. 4(1), https://journal.unnes.ac.id/sju/ index.php/solidarity/article/view/6039

Linarwati, M., Fathoni, A., \& Minarsih, M. M. (2016). Studi deskriptif pelatihan dan pengembangan sumberdaya manusia serta penggunaan metode behavioral event interview dalam merekrut karyawan baru di Bank Mega Cabang Kudus. Journal of Management. 2(2), https://jurnal. unpand.ac.id/index.php/MS/article/view/604/588

Moleong, L. J. (2001). Metodologi penelitian kualitatif. Remaja Rosdakarya.

Mulkhan, A. M. (2000). Islam murni dalam masyarakat petani. Bentang Budaya.

Mukarromah, S., \& Devi, S. I. (2013). Mobilisasi massa partai melalui seni pertunjukan Reog di Ponorogo tahun 1950-1980. Jurnal Verleden, 1(1), 67-68. http://www.journal.unair.ac.id/filerPDF/7_SURURIL.pdf

Nakamura, M.(2017). Bulansabit terbitdiatas pohon beringin:Studi tentang pergerakan Muhammadiyah di Kotagede sekitar 1910-2010. Suara Muhammadiyah dan UMY Press.

Peacock, J. L., (1978). Muslim puritan: Reformist psychology in Southeast Asian Islam. University of California Press.

Peursen, C.A. (1988). Strategi kebudayaan. Kanisisus.

Perbawasari, S., \& Setianti, Y. (2013). Komunikasi dalam transformasi budaya perusahaan. Jurnal Penelitian Komunikasi. 16(1), 1-12. https://doi. org/10.20422/jpk.v16i1.23

Perreault, W. D., \& McCarthy, E. J. (2006). Essentials of marketing: A globalmanagerial ppproach, Tenth Edition. McGraw-Hill

Rahmat, J. (2009). Psikologi agama. Grafindo.

Ritzer, G., \& Goodman, J. D. (2010). Teori sosiologi: Dari klasik hingga perkembangan mutahir. Terj. Nurhadi. Kreasi Wacana

Roosa, J. (2008). Dalih pembunuhan massal. Hasta Mitra

Salim, A. (2006). Teori dan paradigma penelitian sosial. Tiara Wacana

Sambas, S. (2016). Antropologi komunikasi. Pustaka Setia

Semiun, Y. (2006). Teori kepribadian dan terapi psikoanalistik Freud. Kanisius

Singh, A.K. (2004). Tests, measurements, and research methods in behavioral sciences. Bharati Bhawan.

Stewart, C.J., \& Cash W.B. (1982). Interviewing principles and practices. 3rd edition. Wm. C. Brown Company Publisher 
Ngenger tradition and ideology transformation ... (Anang Masduki, Dani Fadillah, Fajar Dwi Putra)

Siswanto. (2017). Transformasi Pancasila dan identitas keindonesiaan. Jurnal Penelitian Politik. 14(1), 55-68. https://doi.org/10.14203/jpp.v14i1.687.

Sztompka, P. (2007). Sosiologi perubahan sosial. Prenada Media Grup

Soekanto, S. (2009). Peranan sosiologi suatu pengantar. Rajawali Press

Sugiyono. (2014). Memahami penelitian kualitatif. Alfabeta

Suharti, S. (2010). Ngenger dalam novel Anteping Tekad. Skripsi Fakultas Pengetahuan Budaya Universitas Indonesia.

Sulistiyo, H. (2003). Palu arit di ladang tebu. Gramedia

Suratno, A., Wohangara, B. R., Retnaningsih, C., Dukut, E. M., Hartayanie, L., Lindayani, M. P. M., Susilorini, M. I. R.,Kurniasari, W. (2018). 50 fakta Jawa. Unika Soegijapranata

Tilaar, H.A.R. (2012). Perubahan sosial dan pendidikan: Pengantar pedagogik transformatif untuk Indonesia. Rineka Cipta.

Wicaksono, B. Y. (2011). Dilema perlindungan hak pekerja rumah tangga anak dalam budaya Ngenger. Jurnal Outlock 9(7), 1-15. https://www. researchgate.net/publication/309662761_Dilema_Perlindungan_Hak_ Pekerja_Rumah_Tangga_Anak_dalam_Budaya_Ngenger

https://grogol-sawoo.desa.id/peta-desa/

Interview with Misnu, a Ngenger person at 5 June 2019

Interview with Imron, a Ngenger person, on 28 June 2019

Interview with Misnu, a Ngenger person at 7 July 2019

Interview with Maskur, a Landlady person at 13 June 2019

Interview with Sudiono, a Ngenger person, on 14 June 2019

Interview with Marwanto, a Ngenger person on 10 July 2019

Interview with Suparni, a Ngenger person at 20 July 2019

Interview with Kuswartini, the wife of Asmaun (a person of Ngenger) at 3 Agust 2019

Interview with Mrs. Anwar, the landlady of Ngenger at 16 July 2019

Interview with Amat, a person of Ngenger, on 22 July 2019

Interview with Murodi, a Ngenger person on 24 July 2019 
Journal of Social Studies (JSS), Volume 17, Number 1, 2021: 37-64 